\title{
Successful loyalty in e-complaints: FsQCA and structural equation modeling
}

\author{
analyses \\ Alberto Urueña*, Antonio Hidalgo \\ Universidad Politécnica de Madrid, c/ José Gutiérrez Abascal, 2, 28006 Madrid, Spain
}

Abstract

This study analyzes antecedents of customer loyalty following complaint behavior in business-to-consumer (B2C) e-commerce. The study uses structural equation modeling (SEM) and fuzzy-set qualitative comparative analysis (fSQCA) to test relationships among distributive, interactional, and procedural justice, positive and neg-ative emotions, satisfaction with service recovery, and trust. Justification for the use of both methods lies in the complementarity and interdependent relationships that exist between the variables. The sample comprises $303 \mathrm{e}$-commerce users who lodge complaints after making online purchases. Results highlight the importance of procedural and interactional justice, positive emotions, and satisfaction with service recovery.

Keywords: Justice, Trust, Emotions, Loyalty, SEM, FsQCA

\section{Introduction}

An increasing number of consumers shift their buying activities from physical stores to retail websites. The reasons for this change are lower prices, more convenience and time savings, and a wider selection of products and services available on websites (Brunner et al., 2014). In Europe, 565 million people already use the Internet ( $79 \%$ of the popula tion), and 47\% make online purchases (Ecommerce Europe, 2014). The percentage of Internet users who purchase online is growing every day. Thus, business to consumer (B2C) e commerce is a flourishing business that allows stores to reach a wider public. Nevertheless, de spite numerous advantages of online shopping, achieving a successful formula for e commerce is difficult.

Despite B2C e commerce firms' efforts to offer high quality services, providing a failure free service seems almost impossible. Service failures can cause dissatisfaction among customers, which may lead to customer complaints and a loss of loyalty in future purchases. To avoid such problems, firms act to rectify service failures through the process of ser vice recovery. Depending on how firms handle service recovery, results may vary massively: from losing an angry customer to retaining a satis fied, relieved one, who may still be willing to purchase again in the future.

This research focuses on the following factors: distributive, procedur al, and interactional justice, positive and negative emotions, satisfaction

* The authors thank Anders Gustafsson, Karlstad University, Gabriel Cepeda and José Luis Roldán, University of Seville, for their careful reading and suggestions on revising this essay.

* Corresponding author.

E-mail addresses: alberto.uruena@upm.es (A. Urueña), antonio.hidalgo@upm.es (A. Hidalgo). with service recovery, and trust. The study addresses two research ques tions. First, what factors should firms apply to ensure customer loyalty following a complaint? Second, does the combination of these factors should be study, in a better approach, using fuzzy set qualitative com parative analysis (fsQCA)?

Section 2 of the article describes antecedents of loyalty through a re view of the literature on complaint behavior and presents the hypothe ses. Section 3 describes the sample, analyzes measurement scales' validity and structural model using traditional structural equation modeling (SEM) and fsQCA, and presents the results with both statisti cal methods. Finally, section 4 discusses conclusions, managerial impli cations, and research limitations.

\section{Antecedent factors of loyalty in complaint behavior}

2.1. Justice as an antecedent of emotions, satisfaction with service recovery, trust, and loyalty

Adams' theory of perceived justice (Adams, 1963) is a highly effec tive tool to study individuals' reactions when engaging in complaint be havior (Río Lanza et al., 2009). Distributive justice consists of the tangible resources the company devotes to correcting and compensat ing for a service failure, including financial compensation, exchanging the item or service, and discounts for future purchases (Mattila, 2001). Procedural justice refers to the processes and methods necessary to ad dress service recovery (Mattila, 2001), including the choice of the most suitable process to solve a problem (Kim et al., 2009). This concept covers aspects such as resolution time, control procedures, and 
execution policies (Maxham \& Netemeyer, 2002) to adapt to customers' needs. Interactional justice refers to how customers experience justice in their interaction with the employees of the firm during the service re covery process (Sparks \& McColl Kennedy, 1998). Several authors ana lyze the relationship between justice and emotions.

Río Lanza et al., (2009) report that distributive and interactional forms of justice do not exert significant influences on negative emo tions. DeWitt et al., (2008) study the influence of perceived justice (without differentiating between components of justice) on positive and negative emotions, observing a greater influence on positive emo tions than on negative emotions. Chebat and Slusarczyk (2005) analyze the effect of justice dimensions on emotions. The authors report that al three dimensions of perceived justice affect negative emotions signifi cantly, and that interactional justice and distributive justice affect posi tive emotions. Distributive justice has a greater effect on positive emotions than on negative emotions. Schoefer and Ennew (2005) find that all three dimensions of justice have significant effects.

McColl Kennedy and Sparks (2003) emphasize the importance of interactional justice in emotions. These authors also state that poor treatment by the employee can cause negative emotions on the custom er, weakening the effects of adequate justice efforts. Procedural justice is a basic requirement because customers expect service providers to have the procedures and speed to correct service failures. In this regard, low levels of procedural justice elicit negative emotions (Schoefer \& Ennew, 2005).

A considerable number of studies deal with justice and satisfaction with service recovery (Karatepe, 2006; Maxham \& Netemeyer, 2002; Schoefer \& Ennew, 2005), and some show that procedural justice has a positive effect on customer satisfaction in service recovery (Homburg \& Fürst, 2005; Karatepe, 2006; Ok et al., 2005; Schoefer \& Ennew, 2005). Satisfaction with service recovery is the feeling of affec tion toward a company resulting from the handling of an interaction complaint (Davidow, 2003).

Other empirical studies show that interactional justice contributes to satisfaction after a complaint (McCollough et al., 2000). Río Lanza et al., (2009) find a positive relationship between interactional justice and satisfaction with service recovery. Interactional justice is important be cause of its intrinsic value (treating someone with respect and polite ness) and its role as a signal to the customer about how the company behaves (Chiu et al., 2010).

Beliefs about a firm's benevolence, competence, and integrity consti tute the concept of trust (Doney \& Cannon, 1997). The majority of un happy customers do not complain, but those who do expect a just response from the organization. Not receiving such a response, or re ceiving an inadequate response, causes the customer to lose trust in the organization (DeWitt et al., 2008). Trust develops over time if the customer feels that the service provider behaves honestly and fairly (Morgan \& Hunt, 1994). Trust is essential to satisfying e commerce cus tomers (Ratnasingham, 1998).

Findings regarding the influence of different types of justice on be haviors such as loyalty, however, are inconclusive (Wang et al., 2011). Effective measures of service recovery can strengthen the customer's trust in the quality of products or services, and develop customer loyal ty. Other research suggests that service recovery efforts to remedy ser vice failures are crucial to maintaining relations with existing customers (Ha \& Jang, 2009). Loyalty refers to continuity in the purchas ing relationship between a customer and a company (Keller, 1993). Loy alty implies that the customer abstains from changing firm, even if he or she must pay more for the service (Shankar et al., 2003). Numerous au thors study the effect of justice in customer retention (Chebat \& Slusarczyk, 2005; McCollough et al., 2000; Wang et al., 2011).

According to these premises, the study tests the following hypotheses:

\section{H1. Justice has negative influence in negative emotions.}

H2. Justice has a positive influence on positive emotions.
H3. Justice has a positive effect on satisfaction with service recovery.

H4. Justice has a positive effect on trust.

H5. Justice positively affects customers' loyalty.

\subsection{Emotions as antecedents of trust, loyalty, and satisfaction with service recovery}

Although research into the influence of emotions on service recov ery are scarce (Río Lanza et al., 2009), some authors report the influence of emotional factors following a complaint (Menon \& Dubé, 2004; Schoefer \& Ennew, 2005; Smith \& Bolton, 2002). The following describes very briefly the relationships studied in the literature between emotions and trust, loyalty, and satisfaction with service recovery.

In this context, whereas Schoefer and Ennew (2005) suggest that perceived justice has a relationship (through emotions) with customer satisfaction, Westbrook (1987) highlights how positive and negative emotions significantly influence customer satisfaction, explaining al most as much variance as other cognitive variables.

Researchers explore the influence of some emotions on trust in ser vice recovery contexts (Kim et al., 2004). Highly negative emotions (e.g., anger) can play a significant moderating role in these processes, and can damage trust. Action to mitigate these types of emotions is like ly to contribute to regaining trust (Kim et al., 2004). In addition, emo tions play an important role in building trust and positive emotions, enabling individuals to make the leap of faith from feelings to beliefs (Andersen \& Kumar, 2006). Wicks et al., (1999) indicate that positive emotions are an indispensable condition for building trust. Findings show that emotions can cause more stable and deeper levels of trust than feelings that stem purely from rational sources (Williams, 2001).

Customers' emotions stemming from perceived justice affect loyalty (DeWitt et al., 2008). Successful service recovery causes an individual to remain loyal to the provider. Conversely, if negative emotions arise, then the customer may become disloyal or may unsubscribe from the service (DeWitt et al., 2008). Affect control theory (ACT) addresses the influence of emotions on loyalty. When customers experience inade quate service recovery, those customers express their emotions and act to regain their own identity (Chebat \& Slusarczyk, 2005).

According to these premises, this study tests the following hypothe ses: negative emotions have a negative influence on satisfaction with service recovery (H6), trust (H7), and loyalty (H8). Positive emotions have a positive influence on satisfaction with service recovery (H9), trust (H10), and loyalty (H11).

\subsection{Satisfaction with service recovery as an antecedent of trust and loyalty}

Finally, studies in scientific literature report connections among sat isfaction with service recovery, trust, and loyalty. In service recovery, customer trust reflects how willing customers are to embrace their vul nerability and expect a positive solution after experiencing service fail ure (Dunn \& Schweitzer, 2005). When customers receive unsatisfactory responses to complaints, those customers lose trust in their service pro vider (DeWitt et al., 2008); likewise, satisfactory resolution of com plaints may increase customers' trust in the provider. Trust develops over time if the customer perceives the provider is reliable, and behaves fairly and honestly (Morgan \& Hunt, 1994). Trust is essential for creating satisfied, loyal customers in e commerce (Ratnasingham, 1998).

The literature reports links between customers' loyalty and their levels of satisfaction. Nevertheless, the literature reveals a lack of con sensus on satisfaction's effect on loyalty. Although a relationship exists between satisfaction and loyalty, satisfaction explains around $8 \%$ of the variance in loyalty, with this figure improving with the inclusion of a greater number of moderating and mediating variables. Whereas some studies report a linear relationship between satisfaction and loyal ty, others indicate that the relation is non linear and asymmetric, with 
satisfaction often a necessary but not sufficient condition for loyalty (Kumar et al., 2013). Levels of agreement between customers and em ployees also relate to satisfaction (Chang \& Chang, 2010; Kelley \& Davis, 1994). Andreassen (2001) indicates that customers' satisfaction with service recovery has a positive relationship with loyalty. Therefore, satisfaction with service recovery positively influences trust (H12) and loyalty (H13).

\subsection{Trust as an antecedent of loyalty}

Trust largely determines the establishment and maintenance of rela tionships between customers and providers and plays a fundamental role in developing loyalty in online environments (Kim et al., 2004). To gain customers' loyalty, vendors must first gain customers' trust (Reichheld et al., 2000). Additionally, the spatial and temporal separa tion between purchasers and sellers in B2C e commerce means that trust is a key factor in maintaining loyalty (Chiu et al., 2010).

Trust is also key to building relationships between buyer and seller (Sirdeshmukh et al., 2002). In any relationship of this kind, customers' trust evaluations directly influence their post purchase satisfaction (Singh \& Sirdeshmukh, 2000). In electronic commerce, where trust may act as a trigger to initiate a transaction, this relationship may also hold. Customers perceive a higher level of risk with online retailers than traditional retailers do in terms of delivery, payment, information disclosure, and so forth. B2C e commerce customers may therefore pre fer to buy from online retailers they can trust (Singh \& Sirdeshmukh, 2000). Therefore, trust positively influences loyalty (H14).

Fig. 1 presents the study's model and the research hypotheses.

\section{Method and results}

\subsection{Sample and procedure}

Research on service recovery often takes the form of laboratory studies, but this empirical research, following other studies (Chebat \& Slusarczyk, 2005), is a field study of users who experienced service problems. An online questionnaire validates the research model. Respondents come from a sample of an official database of B2C e commerce. The owner of this database is the public corporate entity Red.es, responsible for promoting and studying the development of the information society in Spain. The sample designs for the database are a random proportional stratification following population size, location of the household social class, and number of persons per household; the sample has a pattern similar to that of other reports of B2C e commerce in Spain. Customers in this database received an email asking whether they purchased a product or service through the Internet during the previous year. If they answered yes, a second ques tion asked whether they experienced any kind of problem and whether they had complained. Those who answered yes to all questions then re ceived an invitation to participate in the survey.

First, participants had to recall the last time they had experienced a service failure with an Internet purchase about which they had complained. Participants named the e vendor and the specific failure.

From the initial sample of 5000 Internet users, 59\% declared that they had made an online purchase in the last year. Of this 59\%, 10.3\% experienced failures with their purchases and lodged some kind of complaint with the company or an ombudsman. The response rate of e shoppers who lodged complaints about purchase problems is $6.07 \%$, a normal figure for service recovery studies (Gustafsson, 2009). The final sample consists of 303 respondents who issued at least one complaint after a B2C transaction in the previous year, and experienced service recovery actions from vendors following their complaint. Inter viewees also gave the main reason for their complaint. The main rea sons are delays in delivery (41.6\%), defective products $(38.9 \%)$, and receipt of the wrong product (29.4\%). The field study took place between May and July 2012. Table 1 shows the socio demographic characteristics of the sample.

The scales come from previous studies: justice (Chebat \& Slusarczyk, 2005; Chiu et al., 2010; Tax et al., 1998), satisfaction with service recov ery (Kim et al., 2009; Maxham \& Netemeyer, 2002; Tax et al., 1998), negative and positive emotions (Chebat, 2005; DeWitt et al., 2008 Río Lanza et al., 2009), trust (Chiu et al., 2010; DeWitt et al., 2008; Kim et al., 2009; Tax et al., 1998) and loyalty (Chebat \& Slusarczyk, 2005; DeWitt et al., 2008). All items use seven point Likert scales.

Following Chiu et al., (2010), justice is a formative indicator, com prising distributive justice, procedural justice, and interactional justice. To evaluate formative indicators, the examination of the weights using SPSS software provides information about how the indicator contrib utes to the construct. The results show that procedural justice and inter actional justice have weights of 0.93 and distributive justice has a weight of 0.43 . Multicollinearity should be absent from formative indicators. If present, multicollinearity could lead to unstable results. Variance inflation factors (VIF) are 4.7 (procedural justice), 3.7 (distrib utive justice), and 3.6 (interactional justice), all below the limit of 5 (Hair et al., 2010).

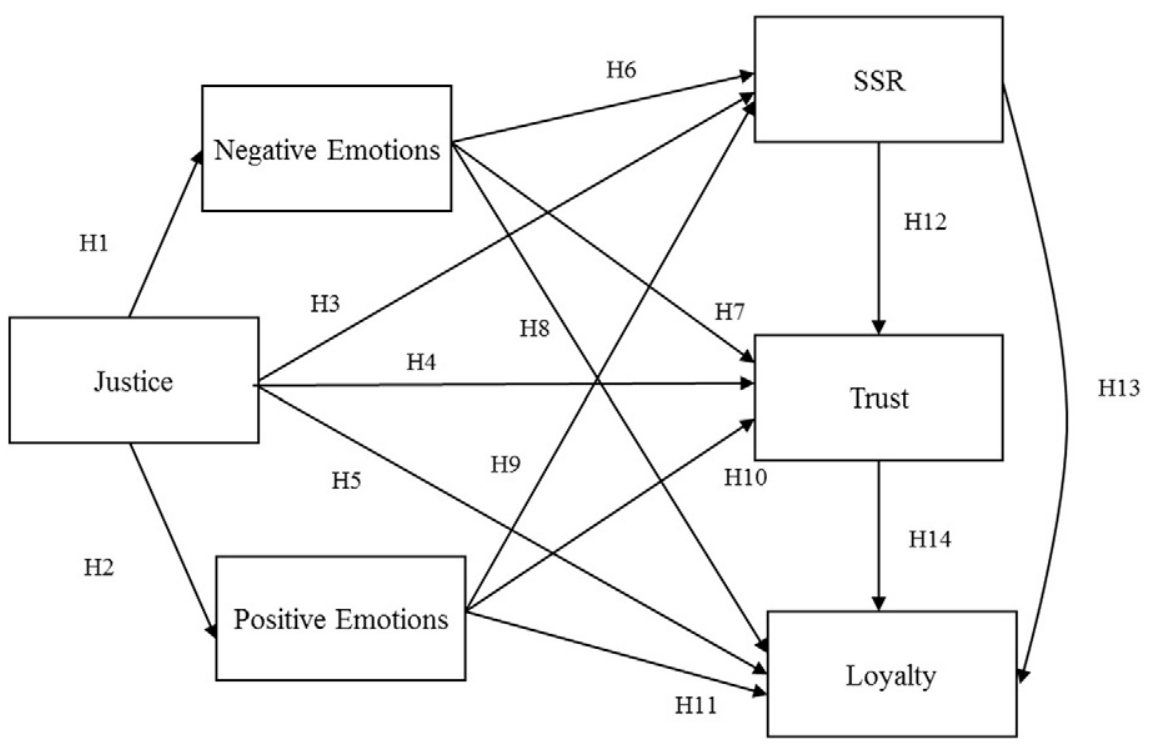

Fig. 1. Research model. 
Table 1

Socio-demographic characteristics of the sample.

\begin{tabular}{llc}
\hline & & Percentage \\
\hline Sex & Male & 66.7 \\
Age & Female & 33.3 \\
& $16-24$ & 13.9 \\
& $25-34$ & 26.4 \\
& $35-49$ & 49.8 \\
Employment status & $50-64$ & 9.2 \\
& $>65$ & 0.7 \\
& Self-employed & 13.2 \\
& Employee & 60.4 \\
& Unemployed & 7.9 \\
Education & Retired & 3.0 \\
& Student & 10.9 \\
& Other & 4.7 \\
& Primary/compulsory & 4.3 \\
& Secondary & 38.3 \\
& Higher education & 46.9 \\
& Postgraduate & 10.6 \\
\hline
\end{tabular}

The next section describes data analysis using SEM and fsQCA. 3.2. Structural equation modeling (SEM)

Partial Least Squares (PLS) is a SEM technique that allows analyzing non normal data with small samples. The study uses PLS Graph version 3.00 to analyze the data through (1) measurement model testing and (2) structural model testing: explained variance of the endogenous var iables $\left(\mathrm{R}^{2}\right)$, path coefficients or standardized linear regression weights $(\beta)$ and their respective levels of significance.

Prior to analyzing the measurement model, a test is necessary to ver ify single item reliability of reflective indicators measuring the factor loadings of the variable indicators. Reflective indicators should present factor loadings greater than 0.707 (Hair et al., 2010), although loadings of 0.50 .6 may be acceptable in preliminary phases (Esposito et al., 2010). In the present study, all the factor loadings exceed 0.90 , except one of the loyalty indicators, whose value (0.79) nonetheless exceeds the lower limit by a wide margin (Nunnally, 1978). From these results, all indicators are valid at this stage.

Next, this method requires a composite reliability analysis, a Cronbach's alpha measurement, and an analysis of the average variance extracted (AVE) from the constructs. These values should be greater than 0.7, 0.7, and 0.5, respectively (Fornell \& Larcker, 1981; Hair et al., 2010). In this case, the values for Cronbach's alpha are greater than 0.87 , values of composite reliability are greater than 0.92 , and the aver age variance extracted is greater than 0.8 (Table 2 ).

Average variance extracted (AVE) analysis tests discriminant validi ty. This analysis consists of verifying that the average shared variance between a construct and its measurement scales is greater than the shared variance between the construct and the other constructs in the model (i.e., squared correlation between two constructs). Here, the square root of the AVE is higher than the correlations between con structs, and is greater than 0.7 (Fornell \& Larcker, 1981). Furthermore, correlations between different constructs confirm that every construct differs from all others (Kline, 1998).

\subsection{Fuzzy set qualitative comparative analysis ( $f S Q C A$ )}

QCA is a family of methods that provides an alternative to regression based analysis. Using fsQCA, researchers can explore com plex causal patterns among different causal or independent variables by studying a small number of cases. By considering causal configura tions, fsQCA does not analyze how two or more independent variables affect an outcome, but rather explores all possible interactions among variables. These interactions are of great interest in studies of complaint behavior. Different combinations of causal factors can thereby lead to the same outcome. Depending on the context and potential combina tion with other factors, an outcome can derive from the presence or ab sence of a certain causal factor.

As per Ragin (1987), by analyzing causality according to context and background, fsQCA yields different underlying causal configurations arising from comparison between diverse case studies. For the Likert scales in this study, 7 represents full membership in a category, 1 repre sents non membership in a category, and 4 represents maximum inde termination regarding membership in a category (Leischnig et al., 2014).

In fsQCA, the choice of solution depends on two parameters: consis tency and coverage. Taking a value between 0 and 1 , consistency indi cates the proportion of a causal condition that the outcome covers. In some sense, consistency is similar to the coefficient of correlation, and constitutes a test of the solution's sufficiency (Woodside, 2013). Cover age is thus similar to the coefficient of determination $\left(R^{2}\right)$.

A solution or path is informative when its consistency is above 0.750 .80 , and its coverage is between 0.25 and 0.65 , although small variations are also acceptable. The final step is to calculate the raw cov erage (indicating which share of the outcome a certain alternative path explains) and unique coverage (indicating which share of the outcome a certain alternative path exclusively explains). Three types of solution exist in fsQCA: complex, parsimonious, and intermediate. The complex solution contains the most detail. This solution assumes that configura tions that do not present real cases in the sample would not lead to the outcome.

\section{Results}

\subsection{Structural model results}

The evaluation of the structural model consisted of a bootstrapping procedure using three indicators: path coefficients $(\beta)$, t statistics, and explained variance $\left(R^{2}\right)$. All the paths except negative emotions trust and satisfaction with service recovery loyalty were significant, and therefore the evaluation only rules out $\mathrm{H} 7$ and $\mathrm{H} 13$ (Fig. 2). The rest of the hypotheses remain: Justice has negative/positive influence in negative/positive emotions; positive emotions have positive influ ence on satisfaction with service recovery, trust, and loyalty; negative emotions have a negative influence on satisfaction with service

Table 2

Descriptive statistics and correlation matrix.

\begin{tabular}{|c|c|c|c|c|c|c|c|c|c|c|}
\hline & Composite reliability & Cronbach's Alpha & AVE & Mean (STD) & (1) & (2) & (3) & $(4)$ & (5) & (6) \\
\hline Justice (1) & - & - & - & $4.02(1.91)$ & - & & & & & \\
\hline Positive_emotions (2) & 0.96 & 0.96 & 0.89 & $3.64(1.92)$ & 0.68 & 0.93 & & & & \\
\hline Negative_emotions (3) & 0.97 & 0.95 & 0.91 & $3.97(2.05)$ & 0.56 & 0.6 & 0.95 & & & \\
\hline Loyalty (6) & 0.92 & 0.87 & 0.8 & $4.07(1.74)$ & 0.61 & 0.62 & 0.5 & 0.68 & 0.64 & 0.89 \\
\hline
\end{tabular}

Diagonal elements (bold) are the square root of the variance shared between the constructs and their measures (AVE). Off-diagonal elements are the correlations among constructs. 


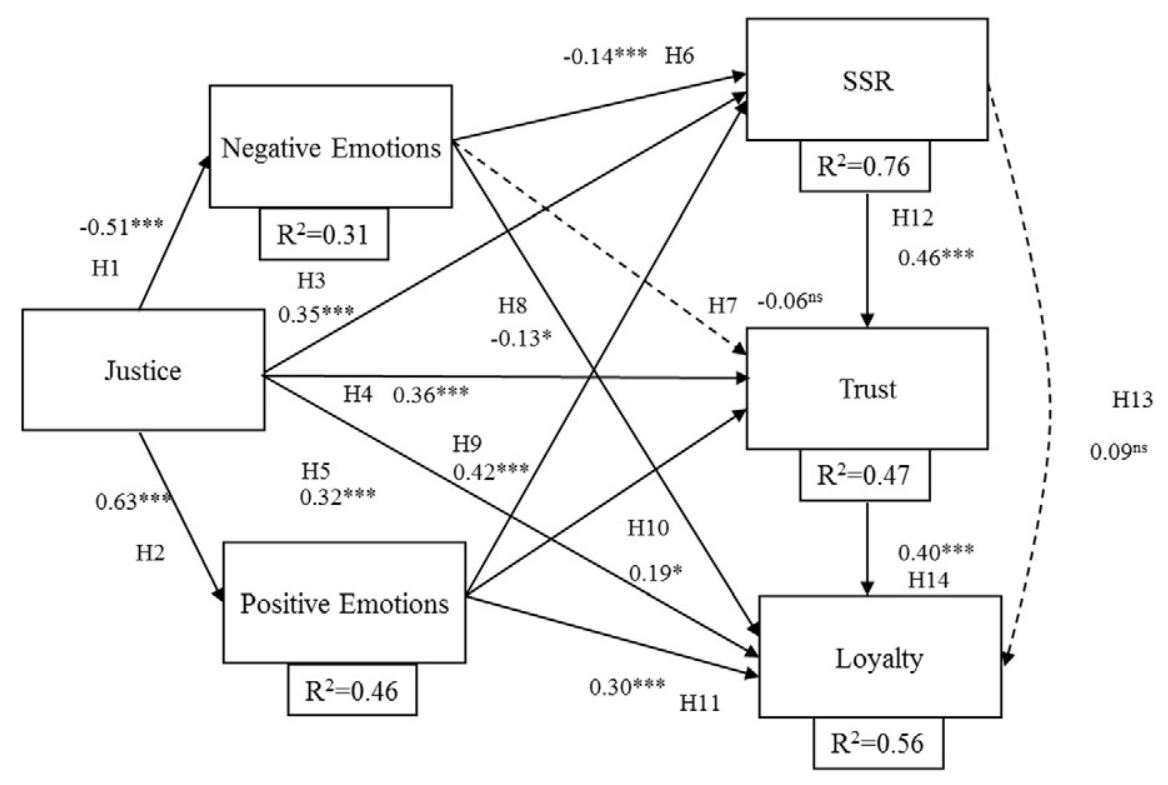

Fig. 2. Results of the research model using SEM.

recovery and loyalty; last, satisfaction with service recovery positively influences trust and trust positively influences loyalty.

The $\mathrm{R}^{2}$ values indicate a good explanation of the model building on the constructs. For the dependent variables, the variance in the explana tion of loyalty is above $50 \%$.

Results show that most correlation coefficients range between 0.47 and 0.68 (Table 2), which implies an asymmetric relationship between variables (Woodside, 2013). When correlation coefficients among vari ables fall below 0.70 , relations are asymmetric and different combina tions of independent variables may yield the same outcome. Second, although less than 5 , multicollinearity is relatively high, which may cause problems when conducting multiple regression analysis (MRA) (Van der Meer et al., 2005; Woodside, 2013). Third, studies on complaint behavior show a high cause effect interdependence among variables. Hence, fsQCA is a suitable, complementary tool for identifying anteced ents of customer loyalty following complaint behavior. FsQCA avoids problems arising from the use of regression methods. The fsQCA method thereby responds to the second research question in the introduction.

\subsection{FsQCA results}

Table 3 shows the complex solutions that lead to customer loyalty. Black circles represent the presence of a causal condition, and white cir cles represent the absence or negation of a causal condition. Blank cells represent irrelevant conditions.

Regarding the complete sample, solution 1 shows that high loyalty re sults from high procedural and interactional justice, low (positive and negative) emotions, and high trust. This solution has a consistency of 0.93 and explains a good number of cases (coverage $=0.43$ ). Solution 2 indicates that high procedural and interactional justice, high positive emotion and low negative emotion, and high satisfaction with service re covery lead to highly loyal consumer behavior. Of the three solutions, solution 2 explains the most cases (raw coverage $=0.68$ ), and has a con sistency of 0.92 . Solution 3 shows that the combination of high distribu tive and procedural justice, high positive emotions during the complaint process, low negative emotions, high satisfaction with service recovery, and high trust result in loyalty (consistency $=0.94$ and raw coverage $=$ 0.63). Thus, the three solutions (paths 1,2, and 3) all contain the condi tions of high procedural justice and low negative emotions, which implies that these conditions are necessary to achieve high customer loyalty.

\section{Conclusions and limitations}

\subsection{Conclusions}

From a methodological perspective, this research demonstrates the usefulness of combining traditional techniques, namely SEM, with fsQCA techniques. SEM techniques let researchers observe the strength of relationships between variables in the model, whereas fsQCA yields configurations between variables that lead to a certain outcome in this study, loyalty following complaint behavior. Researchers should view the two approaches as complementary.

From a theoretical perspective, this study contributes to the scientific literature on service recovery by proposing a model that reports configural paths to loyalty using justice, positive and negative emotions, satisfaction with service recovery, and trust as antecedents of loyalty. Most service recovery studies consider satisfaction with service recovery (i.e., cumulative satisfaction) an output, but other marketing variables such as customer loyalty are also important when explaining future con sumer behavior. This research pioneers the study of the influence of $\operatorname{cog}$ nitive and emotional factors using fsQCA in a service recovery context.

A relevant point relates to the implications concerning justice. Proce dural justice and interactional justice are key antecedents to loyalty. When a problem appears in B2C e commerce service recovery,

Table 3

FsQCA output: Loyalty.

\begin{tabular}{|c|c|c|c|c|c|c|c|c|c|c|c|}
\hline Group & $\begin{array}{l}\text { Path } \\
\text { no. }\end{array}$ & Causal conditions & & & & & & & $\begin{array}{l}\text { Raw } \\
\text { coverage }\end{array}$ & $\begin{array}{l}\text { Unique } \\
\text { Coverage }\end{array}$ & Consistency \\
\hline All samples & 1 & Distributive justice & Procedural justice & Interactional justice & $\begin{array}{c}\text { Positive emotions } \\
\bigcirc\end{array}$ & $\begin{array}{c}\text { Negative emotions } \\
\bigcirc\end{array}$ & SSR & Trust & 0.435985 & 0.028042 & 0.934457 \\
\hline & 2 & & ○ & ○ & - & 0 & - & & 0.687984 & 0.024489 & 0.924073 \\
\hline & 3 & 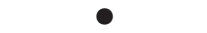 & $\bullet$ & & - & O & 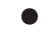 & $\bullet$ & 0.639577 & 0.003743 & 0.944444 \\
\hline
\end{tabular}


customers seem to value positively the company's efforts and proce dures to re establish the service as soon as possible. The special influ ence of negative emotions on loyalty may have its origin in the problems shoppers report with online purchases. Because logistical and payment problems often stem from provider companies that oper ate under their own trade name and do not deal directly with the B2C e commerce platform, such problems may be situational and beyond the control of the B2C e commerce vendor. Nevertheless, these problems evoke negative emotions in customers. In addition, understanding the role of positive emotions is important because emotions receive little at tention in service recovery studies.

From the managerial perspective, results reveal the importance of training employees in how to manage customer emotions in a com plaint situation through role playing and techniques to detect emotions during telephone conversations or e mails. Simultaneously, managers should be aware of the difficulties this process entails in an online envi ronment because of a lack of face to face interaction with the customer. Providing employees with appropriate training and technological re sources (e.g., webcams for videoconferences) that enable them to rec ognize customers' emotions more accurately can improve the quality of interactions.

\subsection{Limitations}

The study has some limitations. Future studies should explore addi tional antecedents of loyalty (e.g., perceived value or quality following a complaint) and investigate emotions in a more specific manner by in corporating a larger battery of emotional responses and studying their influence on loyalty. Such research would provide a more comprehen sive explanation in service recovery contexts. Finally, an alternative ap proach to improving the current model would be considering the affective and cognitive components of trust.

\section{References}

Adams, J. S. (1963). Toward an understanding of inequity. Journal of Abnormal and Social Psychology, 67(5), 422-436.

Andersen, P. H., \& Kumar, R. (2006). Emotions, trust and relationship development in business relationships: A conceptual model for buyer-seller dyads. Industrial Marketing Management, 35(4), 522-535.

Andreassen, T. W. (2001). From disgust to delight: Do customers hold a grudge? Journal of Service Research, 4(1), 39-49.

Brunner, A., Scholl, U. S., \& Stokburger, N. (2014). The relevance of holistic website perception. How sense-making and exploration cues guide consumers' emotions and behaviors. Journal of Business Research, 67(12), 2515-2522.

Chang, Y., \& Chang, H. (2010). Does service recovery affect satisfaction and customer loyalty? An empirical study of airline services. Journal of Air Transport Management, 16(6), 340-342.

Chebat, J. C., \& Slusarczyk, W. (2005). How emotions mediate the effect of perceived justice on loyalty in service recovery situations: An empirical study. Journal of Business Research, 58(5), 664-673.

Esposito, V., Chin, W., Henseler, J., \& Wang, H. (2010). Handbook of partial least squares: Concepts, methods and applications in marketing and related fields. Berlin: Springer.

Chiu, C. M., Huang, H. Y., \& Yen, C. H. (2010). Antecedents of trust in online auctions. Electronic Commerce Research and Applications, 9(2), 148-159.

Davidow, M. (2003). Have you heard the word? The effect of word of mouth on perceived justice, satisfaction and repurchase intentions following complaint handling. Journa of Consumer Satisfaction, Dissatisfaction and Complaining Behavior, 16(3), 67-80.

DeWitt, T., Nguyen, D. T., \& Marshall, R. (2008). Exploring customer loyalty following service recovery. Journal of Service Research, 10(3), 269-281.

Doney, P. M., \& Cannon, J. P. (1997). An examination of the nature of trust in buyer-seller relationships. Journal of Marketing, 61(2), 35-51.

Dunn, J. R., \& Schweitzer, M. E. (2005). Feeling and believing: The influence of emotion on trust. Journal of Personality and Social Psychology, 88(5), 736-748.

Ecommerce Europe (2014). Europe B2C Ecommerce report 2014. Available online at http://www.ecommerce-europe.eu/home

Fornell, C., \& Larcker, D. F. (1981). Evaluating structural equation models with unobservable variables and measurement error. Journal of Marketing Research, 18(1), 39-50.

Gustafsson, A. (2009). Customer satisfaction with service recovery. Journal of Business Research, 62(11), 1220-1222.

Ha, J., \& Jang, S. (2009). Perceived justice in service recovery and behavioral intentions: The role of relationship quality. International Journal of Hospitality Management, 28(3), 319-327.

Hair, J. F., Black, B., Babin, B., \& Anderson, R. E. (2010). Multivariate data analysis. Upper Saddle River, N.J.: Pearson Prentice Hall.
Homburg, C., \& Fürst, A. (2005). How organizational complaint handling drives customer loyalty: An analysis of the mechanistic and the organic approach. Journal of Marketing, 69(3), 95-114.

Karatepe, O. M. (2006). Consumer complaints and organizational responses: The effects of complainants' perceptions of justice on satisfaction and loyalty. Journal of Hospitality and Management, 25(1), 69-90.

Keller, K. L. (1993). Conceptualizing, measuring, and managing customer-based brand equity. Journal of Marketing, 57(1), 1-22.

Kelley, S. W., \& Davis, M. A. (1994). Antecedents to customer expectations for service recovery. Journal of the Academy of Marketing Science, 22(1), 52-61.

Kim, P. H., Ferrin, D. L., Cooper, C. D., \& Dirk, K. (2004). Removing the shadow of suspicion: The effects of apology versus denial for repairing competence- versus integrity-based trust violations. Journal of Applied Psychology, 89(1), 104-118.

Kim, T., Kim, W. G., \& Kim, H. (2009). The effects of perceived justice on recovery satisfaction, trust, word-of-mouth, and revisit intention in upscale hotels. Tourism Management, 30(1), 51-62.

Kline, R. B. (1998). Principles and practice of structural equation modeling. New York: Guilford Press.

Kumar, V., Ilaria, P., \& Jaishankar, G. (2013). Revisiting the satisfaction-loyalty relationship: Empirical generalizations and directions for future research. Journal of Retailing, 89(3), 246-262.

Leischnig, A., Geigenmueller, A., \& Lohmann, S. (2014). On the role of alliance management capability, organizational compatibility, and interaction quality in interorganizational technology transfer. Journal of Business Research, 67(6), 1049-1057.

Mattila, A. (2001). The effectiveness of service recovery in a multi-industry setting. Journal of Services Marketing, 15(7), 583-596.

Maxham, J. G., \& Netemeyer, R. G. (2002). Modeling customer perceptions of complaint handling over time: The effects of perceived justice on satisfaction and intent. Journal of Retailing, 78(4), 239-252.

McColl-Kennedy, J. R., \& Sparks, B. A. (2003). Application of fairness theory to service failures and service recovery. Journal of Service Research, 5(3), 251-266.

McCollough, M. A., Berry, L. L., \& Yadav, M. S. (2000). An empirical investigation of customer satisfaction after service failure and recovery. Journal of Service Research, 3(2), 121-137.

Menon, K., \& Dubé, L. (2004). Service provider responses to anxious and angry customers: Different challenges, different payoffs. Journal of Retailing, 80(3), 229-237.

Morgan, R. M., \& Hunt, S. D. (1994). The commitment-trust theory of relationship marketing. Journal of Marketing, 58(3), 20-38.

Nunnally, J. (1978). Psychometric theory. New York: McGraw-Hill.

Ok, C., Back, K., \& Shanklin, C. W. (2005). Modeling roles of service recovery strategy: A relationship-focused view. Journal of Hospitality and Tourism Research, 29(4), 484-507.

Ragin, C. C. (1987). The comparative method: Moving beyond qualitative and quantitative strategies. Berkeley: University of California Press.

Ratnasingham, P. (1998). Trust in web-based electronic commerce security. Information Management E Computer Security, 6(4), 162-166.

Reichheld, F. F., Markey, R. G., \& Hopton, C. (2000). E-Customer loyalty - Applying the traditional rules of business for online success. European Business Journal, 12(4), 173-179.

Río-Lanza, A. B., Vázquez-Casielles, R., \& Díaz-Martín, A. M. (2009). Satisfaction with service recovery: Perceived justice and emotional responses. Journal of Business Research, 62(8), 775-781.

Schoefer, K., \& Ennew, C. (2005). The impact of perceived justice on consumer emotional responses to service complaints experiences. Journal of Services Marketing, 19(5), 261-270.

Shankar, V., Smith, A. K., \& Rangaswamy, A. (2003). Customer satisfaction and loyalty in online and offline environments. International Journal of Research in Marketing, 20(2), 153-175.

Singh, J., \& Sirdeshmukh, D. (2000). Agency and trust mechanisms in consumer satisfaction and loyalty judgments. Journal of the Academy of Marketing Science, 28(1), $150-167$.

Sirdeshmukh, D., Singh, J., \& Sabol, B. (2002). Consumer trust, value and loyalty in relational exchanges. Journal of Marketing, 66(1), 15-37.

Smith, A. K., \& Bolton, R. N. (2002). The effects of customers, emotional responses to service failures on their recovery effort evaluations and satisfaction judgments. Journal of the Academy of Marketing Science, 30(1), 5-23.

Sparks, B. A., \& McColl-Kennedy, J. R. (1998). The application of procedural justice principles to service recovery attempts: Outcomes for customer satisfaction. Advances in Consumer Research, 25(1), 156-161.

Tax, S. S., Brown, S. W., \& Chandrashekaran, M. (1998). Customer evaluations of service complaint experiences: Implications for relationship marketing. Journal of Marketing, 62(2), 60-76.

Van der Meer, R. B., Quigley, J., \& Storbeck, J. E. (2005). Using regression analysis to model the performance of UK coastguard centres. Journal of the Operational Research Society, 56(6), 630-641.

Wang, Y., Wu, S., Lin, H., \& Wang, Y. (2011). The relationship of service failure severity, service recovery justice and perceived switching costs with customer loyalty in the context of e-tailing. International Journal of Information Management, 31(4), 350-359.

Westbrook, R. A. (1987). Product/consumption-based affective responses and post purchase processes. Journal of Marketing Research, 24(3), 258-270.

Wicks, A., Berman, S., \& Jones, T. (1999). The structure of optimal trust: Moral and strategic implications. Academy of Management Review, 24(1), 99-116.

Williams, M. (2001). In whom we trust: Group membership as affective context for trust development. Academy of Management Review, 26(3), 377-396.

Woodside, A. G. (2013). Moving beyond multiple regression analysis to algorithms: Calling for adoption of a paradigm shift from symmetric to asymmetric thinking in data analysis and crafting theory. Journal of Business Research, 66(4), 463-472. 